\title{
TRADYCJA I NOWE PRĄDY W BADANIACH NAD MLODSZYM OKRESEM PRZEDRZYMSKIM W WIELKOPOLSCE
}

\section{TRADITIONAL AND NEW APPROACHES TOWARDS RECOGNITION OF THE EARLY PRE-ROMAN IRON AGE IN WIELKOPOLSKA}

\author{
Andrzej Michatowski \\ Instytut Prahistorii, Uniwersytet im. Adama Mickiewicza \\ ul. Św. Marcin 78, 61-809 Poznań, Poland \\ Milena Teska \\ Instytut Prahistorii, Uniwersytet im. Adama Mickiewicza \\ ul. Św. Marcin 78, 61-809 Poznań, Poland
}

\begin{abstract}
The article presents the history and current developments in the studies of the Pre-Roman Iron Age in Wielkopolska. As it has been shown, there were three cultures, namely the Pomeranian, Przeworsk and Jastorf, which significantly influenced the processes of shaping of the population inhabiting the region at the early stages of the discussed period. It has been also emphasised that there has been currently observed insufficiency of sources, and that there is need for further research on the issues discussed.
\end{abstract}

W archeologii polskiej przyjęło się, iż badania nad problematyką młodszego okresu przedrzymskiego rozpatruje się w nierozerwalnym powiązaniu i nawiązaniu do następującego po nim okresu wpływów rzymskich. W związku z tym okres przedrzymski bywa często spychany jedynie do roli swoistej przygrywki dla tego właściwego momentu dziejowego, jakim jest okres wpływów rzymskich. Sugeruje to już sama jego nazwa, którą upowszechnił w piśmiennictwie archeologicznym R. Hachmann ${ }^{1}$. Postępowanie takie wiąże się z przyjętymi założeniami, iż zachodzące wówczas w środkowej i północnej Europie zmiany stanowią pewną ewolucyjną

\footnotetext{
${ }^{1}$ Hachmann 1961.
} 
drogę rozwojową, ukoronowaną owym „rzymskim” zwieńczeniem. Taki odbiór tej epoki narzuca się już przez pryzmat systemu chronologicznego, periodyzującego okres wpływów rzymskich. Ów podział stworzony przez H.J. Eggersa ${ }^{2}$, a po nim powtarzany i uzupełniany przez innych badaczy, jest bowiem tożsamy dopiero z fazami B i C. Poprzedza je faza A, która zamyka w sobie dzieje środkowoeuropejskich społeczności z czasów dominanty cywilizacyjnej Celtów w dobie środkowego i starszego okresu lateńskiego. Na większości terenów środkowoeuropejskich między obydwoma okresami dostrzegalna jest wyraźna ciągłość kulturowa. Nie zmienia tego nawet fakt zachodzących na obszarze Europy Środkowej w ciągu I w. p.n.e. przekształceń cywilizacyjnych, wynikających ze zmiany układu sił, a będących skutkiem załamania się politycznej hegemonii Celtów oraz stopniowej ekspansji rzymskiej postępującej nad Dunajem i Renem. W odniesieniu do obszarów ziem polskich myślenie takie w szczególności uzasadnia rozwój kultury przeworskiej, powstałej na przełomie III i II w. p.n.e. Trwanie jej osadnictwa jesteśmy w stanie prześledzić aż do $\mathrm{V}$ w. n.e., tj. do czasów jego zaniku, będącego efektem przeobrażeń, jakie spowodował okres wędrówek ludów.

Okres przedrzymski ma jednak swoją wyraźną specyfikę i zagadnienia badawcze, które wyodrębniają studia nad nim w zwartą grupę problemową. W zależności od przyłożenia akcentów poznawczych nie musimy traktować tego momentu dziejowego wyłącznie jako preludium rodzącego się z niego nowego świata, ale można spojrzeć na zachodzące wówczas przemiany jako na kwintesencję transformacji wywodzących się ze starszych tradycji cywilizacyjnych. W takim ujęciu jest to moment rzeczywistej finalizacji czynnego udziału tradycji posthalsztackich, przy ostatecznym zastąpieniu ich przez odceltycki model kulturowy. $\mathrm{Z}$ tego punktu widzenia na plan pierwszy wysuwa się poznanie ciągłości zachodzącej pomiędzy starszym (posthalsztackim) a młodszym (zlatenizowanym) stadium okresu przedrzymskiego. Jest to spojrzenie wyraźnie widoczne w tradycji poznawczej właściwej dla strefy objętej osadnictwem szeroko pojętego kręgu jastorfskiego.

\section{ZARYS DOTYCHCZASOWYCH ZAINTERESOWAŃ PROBLEMATYKĄ MLODSZEGO OKRESU PRZEDRZYMSKIEGO W WIELKOPOLSCE}

Studia nad zagadnieniami młodszego okresu przedrzymskiego w Wielkopolsce mają dość długą i znaczącą tradycję. Wzmianki omawiające materiały datowane na to stadium chronologiczne odnajdujemy w literaturze przedmiotu, poczynając od XIX w. ${ }^{3}$. Niestety prezentowane tamże odkrycia były jedynie wynikiem przypadkowych znalezisk, a nie jakiejś planowej akcji badawczej.

\footnotetext{
${ }^{2}$ Eggers 1955.

${ }^{3}$ Zob. np. Undset 1882; Blume 1909, 1911, 1915; Erzepki, Kostrzewski 1914; Kostrzewski 1919b, $1919 / 1920 \mathrm{i}$ in.
} 


\section{Manmus=Bibliothek \\ herausgegeben vor profeffior Dr. Gufftaf Koffinna \\ itr. 18 \\ Die oftgermanifhe Kultur der Spätlatènezeit}

Doll

\section{Jojef Koftrjewshi}

1. Teil

mit 244 Jex̧tabbiloungen und I Karte

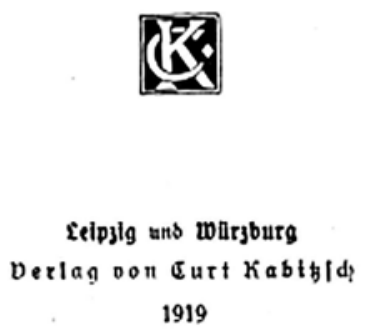

Ryc. 1. Strona tytułowa Die ostgermanische Kultur der Spätlatènezeit autorstwa Józefa Kostrzewskiego z $1914 \mathrm{r}$.

Fig. 1. The title page of Die ostgermanische Kultur der Spätlatènezeit by Józef Kostrzewski, 1914 edition

Materiały te dały jednak podstawy do prób tworzenia pewnych ogólniejszych prac, wnikających w specyfikę pojawiających się w ich wyniku znalezisk, takich jak np. korony zębate omawiane przez Włodzimierza Demetrykiewicza (1900). W szczególności jednak wpływ na ukształtowanie się postrzegania młodszego okresu przedrzymskiego wywarła praca Józefa Kostrzewskiego - Die ostgermanische Kultur der Spätlatènezeit ${ }^{4}$ (ryc. 1). Ustalenia typologiczno-chronologiczne zawarte w tej publikacji nie utraciły do dziś swojej wartości, a przedstawione tam materiały wciąż

\footnotetext{
${ }^{4}$ Kostrzewski 1919a.
} 


\title{
WIELKOPOLSKA W CZASACH PRZEDHISTORYCZNYCH
}

NAPISA1.

\author{
JÓZEF KOSTRZEWSKI
}

Z 557 RYCINAMI W TEKSCIE I NA 8 TABLICACH

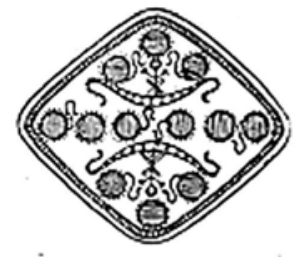

POZNAŃ 1914

NAKŁADEM KSIEGARNI M. NIEMIERKIEWICZA WARSZAWA: E. WENDE I SPÓLKA

Ryc. 2. Strona tytułowa pierwszego wydania Wielkopolski $w$ czasach przedhistorycznych autorstwa Józefa Kostrzewskiego z roku 1914

Fig. 2. The title page of the first issue of Wielkopolska $w$ czasach przedhistorycznych by Józef Kostrzewski, 1914

stanowią istotną bazę danych do prowadzenia dalszych badań nad zagadnieniami młodszego okresu przedrzymskiego. $Z$ jednej strony jest to wynik doskonałego warsztatu twórcy tego opracowania, a z drugiej - niewątpliwy przywilej wszelkich prac materiałowych, które, w odróżnieniu od najbardziej nawet rewolucyjnych ujęć interpretacyjnych, z upływem czasu nie tracą na swojej wartości, w momencie gdy prowadzone dywagacje teoretyczne pokrywa już w większości kurz zapomnienia. Praca ta spowodowała jednak, że wraz z syntetyzującymi ujęciami zawartymi w dwóch wydaniach Wielkopolski w czasach przedhistorycznych ${ }^{5}$ (ryc. 2, 3) zaprezentowany został na tyle wnikliwy obraz interesującego nas okresu, wraz z wyczerpu-

\footnotetext{
${ }^{5}$ Kostrzewski 1914, 1923.
} 
DR. JÓZEF KOSTRZEWSKI

PROFESOR UNIWERSYTETU POZNAŃSKIEGU

\section{WIELKOPOLSKA \\ W CZASACH \\ PRZEDHISTORYCZNYCH}

WYDANIE II-GIE ZMIENIONE

I ZNACZNIE ROZSZERZONE

Z 856 RYCINAMI W TEKŚCIE

I SZESNASTU TABLICAMI.

1923.

POZNAŃ: FISZER I MAJEWSKI

WARSZAWA: E. WENDE I SKA. KODŹ: L. FISZER

TORUN: TOWARZYSTWO WYDAWNICZE, "IGNIS“.

Ryc. 3. Strona tytułowa drugiego wydania Wielkopolski w czasach przedhistorycznych autorstwa Józefa Kostrzewskiego z 1923 r.

Fig. 3. The title page of the second issue of Wielkopolska $w$ czasach przedhistorycznych by Józef Kostrzewski, 1923

jącą bazą materiałową, iż dla Wielkopolski na długo zanikła potrzeba prowadzenia pogłębionych prac syntetycznych nad okresem przedrzymskim. Nie oznaczało to jednak całkowitego poniechania studiów nad tą problematyką. W dwudziestoleciu międzywojennym J. Kostrzewski, w kontekście swoich ówczesnych zainteresowań 
i prowadzonej z badaczami niemieckimi dyskusji na temat ciągłości osadniczej Słowian, zajął się retrospektywnym spojrzeniem na problem związków łączących kulturę materialną początków młodszego okresu przedrzymskiego ze schyłkowymi czasami funkcjonowania horyzontu kultury łużyckiej ${ }^{6}$. W odniesieniu do interesują-

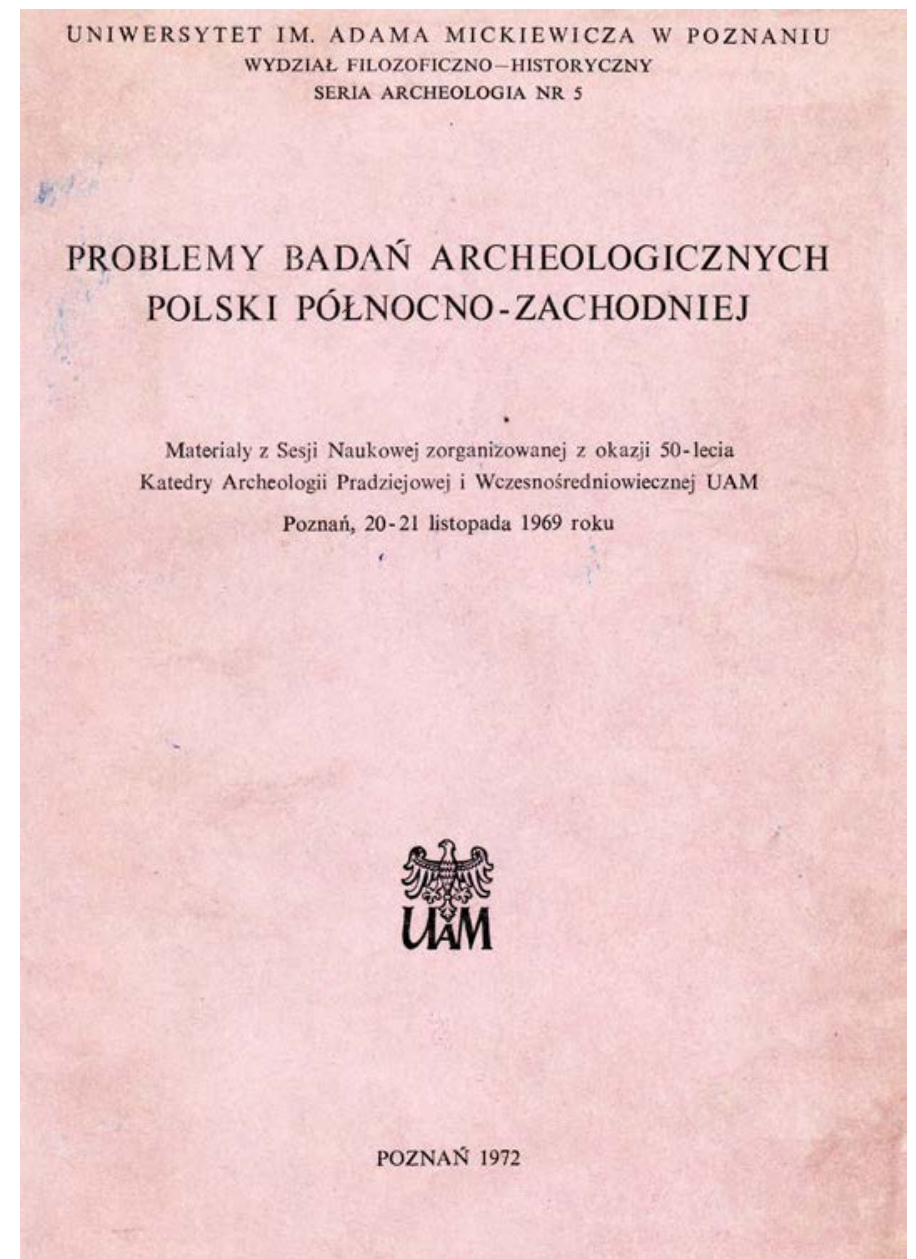

Ryc. 4. Okładka publikacji materiałów z konferencji, zorganizowanej z okazji obchodów 50-lecia istnienia Katedry Archeologii Pradziejowej i Wczesnośredniowiecznej UAM w roku 1969, z referatem Stanisława Jasnosza Kultura okresu późnolateńskiego i wpływów rzymskich w Wielkopolsce (Stan badań)

Fig. 4. The cover of the publication, issued after the conference organised to celebrate the 50th anniversary of the Departement of the Prehistoric and Early Medieval Archaeology at Adam Mickiewicz University in 1969, with a speech delivered by Stanisław Jasnosz: Kultura okresu późnolateńskiego $i$ wptywów rzymskich $w$ Wielkopolsce (Stan badań)

\footnotetext{
${ }^{6}$ Kostrzewski 1933.
} 
STAN I POTRZEBY BADAŃ NAD MŁODSZYM OKRESEM PRZEDRZYMSKIM I OKRESEM WPLYWÓW RZYMSKICH W POLSCE

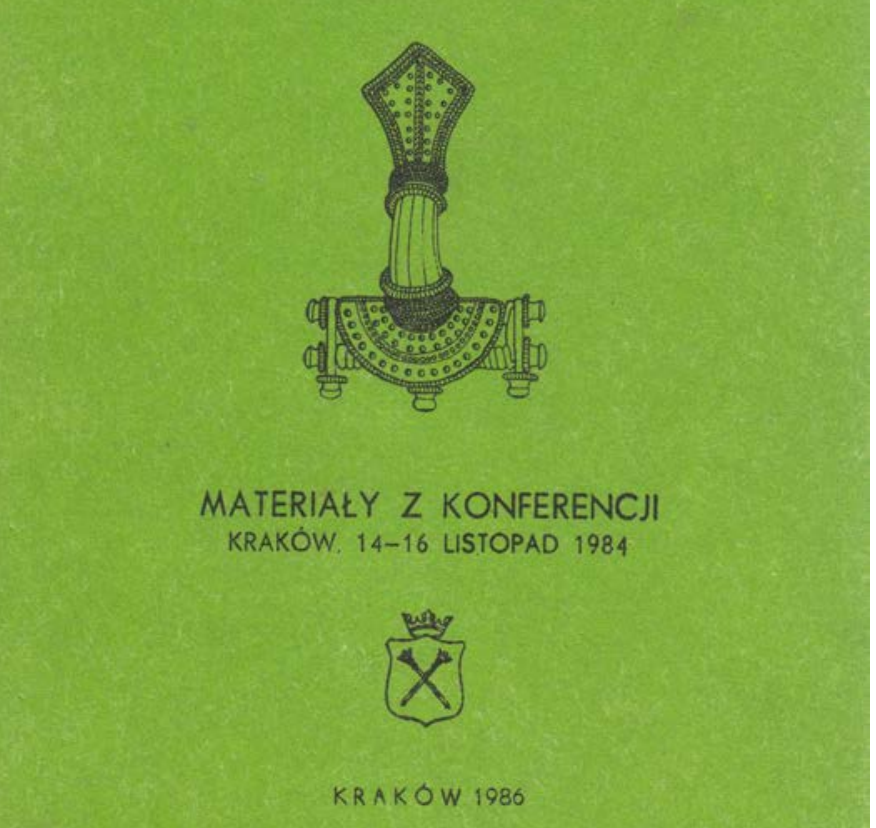

Ryc. 5. Okładka publikacji pokonferencyjnej Stan i potrzeby badań nad młodszym okresem przedrzymskim i okresem wplywów rzymskich w Polsce, z tekstem referatu Henryka Machajewskiego: Stan badań nad mtodszym okresem przedrzymskim i okresem rzymskim $w$ Wielkopolsce

Fig. 5. The cover of the post-conference publication: Stan i potrzeby badan nad mtodszym okresem przedrzymskim i okresem wptywów rzymskich w Polsce, with Henryk Machajewski's article: Stan badań nad młodszym okresem przedrzymskim i okresem rzymskim w Wielkopolsce

jącego nas odcinka dziejów badacz ten podejmował tym samym dyskusję nad kwestiami przynależności etnicznej ówczesnych społeczeństw ${ }^{7}$. Znaczący przyrost bazy źródłowej dla omawianego okresu dziejów nastąpił jednak dopiero w latach 50. XX wieku. Był on efektem badań prowadzonych na wielkich nekropoliach kultury

\footnotetext{
${ }^{7}$ Kostrzewski 1936.
} 
przeworskiej, takich jak Wymysłowo ${ }^{8}$ czy Młodzikowo ${ }^{9}$, oraz na osadzie w KaliszuPiwonicach $^{10}$. Opracowania tychże stanowisk spowodowały ponowne, jak miało to miejsce we wcześniejszych pracach J. Kostrzewskiego, usystematyzowanie na całe lata wiedzy źródłowej. Ukształtowały one tym samym postrzeganie przemian kulturowych zachodzących ówcześnie w Wielkopolsce, tworząc punkty odniesienia dla

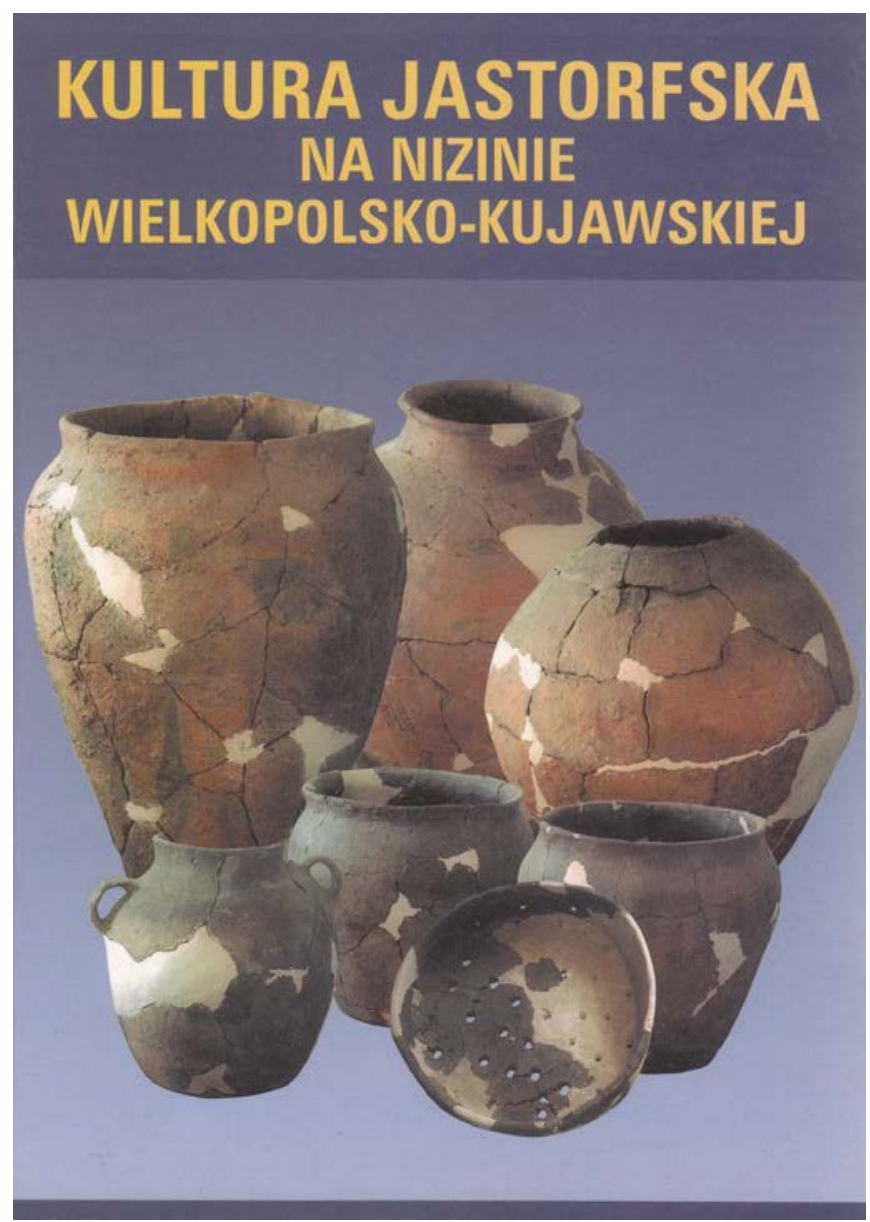

Ryc. 6. Okładka przełomowej dla studiów nad młodszym okresem przedrzymskim publikacji pokonferencyjnej: Kultura jastorfska na Nizinie Wielkopolsko-Kujawskiej z 2004 r.

Fig. 6. The cover of the post-conference publication, a breakthrough in the study on the late Pre-Roman Iron Age: Kultura jastorfska na Nizinie Wielkopolsko-Kujawskiej, published in 2004

\footnotetext{
${ }^{8}$ Jasnosz 1952.

${ }^{9}$ Dymaczewski 1958.

${ }^{10}$ Dąbrowski 1959.
} 
wszelkich dalszych studiów nad problematyką okresu przedrzymskiego. Przez ich pryzmat okres ten jawi się teraz jako wczesne stadium kultury przeworskiej, nieprzerwanie rozwijającej się w głąb okresu wpływów rzymskich, rozpatrywanych łącznie jako swoisty ciąg ewolucyjnego rozwoju tutejszych społeczeństw ${ }^{11}$ (ryc. 4, 5).

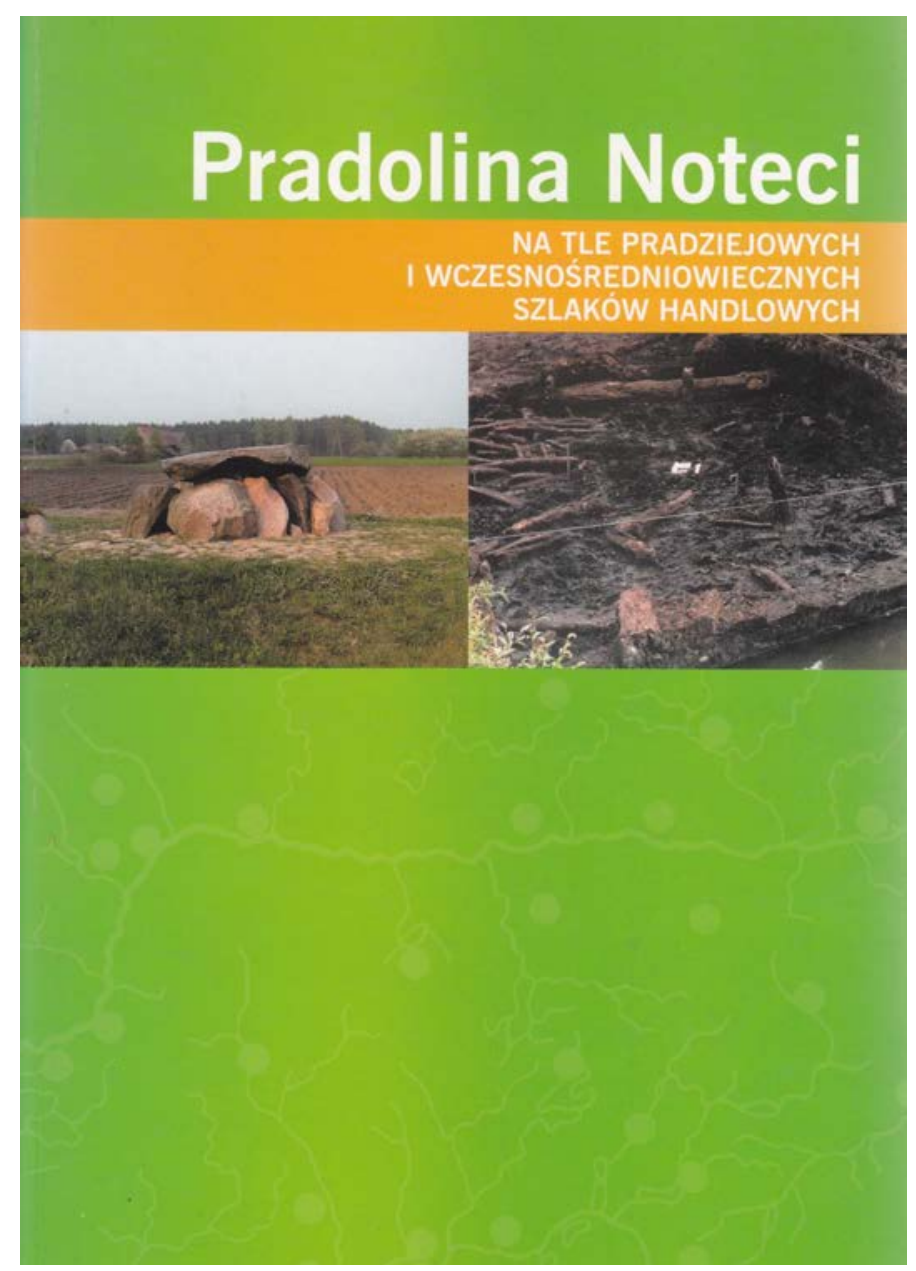

Ryc. 7. Okładka wydanych drukiem materiałów z konferencji Pradolina Noteci na tle pradziejowych $i$ wczesnośredniowiecznych szlaków handlowych, z artykułem Andrzeja Michałowskiego: Kultura jastorfska w Wielkopolsce pótnocnej

Fig. 7. The cover of the book presenting texts delivered during the conference: Pradolina Noteci na tle pradziejowych $i$ wczesnośredniowiecznych szlaków handlowych, with Andrzej Michałowski's article: Kultura jastorfska w Wielkopolsce pótnocnej

\footnotetext{
${ }^{11}$ Por. Jasnosz 1972; Machajewski 1986.
} 


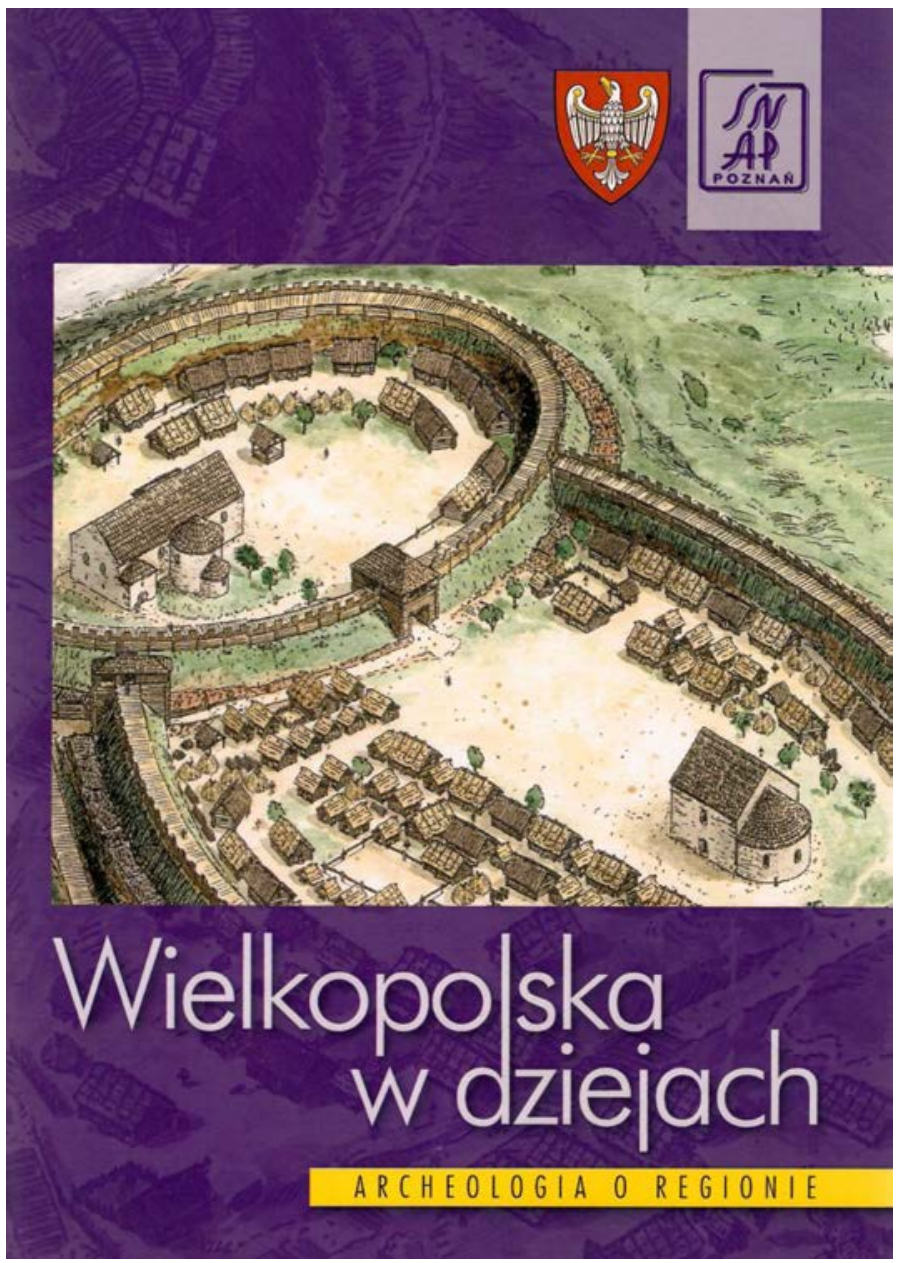

Ryc. 8. Okładka opublikowanych drukiem referatów z konferencji Wielkopolska w dziejach. Archeologia o regionie, $\mathrm{z}$ artykułem Andrzeja Michałowskiego, Okres przedrzymski w Wielkopolsce - najnowsza próba wstępnego, syntetycznego spojrzenia na sytuację kulturowa Wielkopolski w młodszym okresie przedrzymskim

Fig. 8. The cover of published speeches delivered during the conference: Wielkopolska $w$ dziejach. Archeologia o regionie, with Andrzej Michałowski's article: Okres przedrzymski w Wielkopolsce najnowsza próba wstępnego, syntetycznego spojrzenia na sytuację kulturową Wielkopolski w młodszym okresie przedrzymskim

Pewne przewartościowanie spojrzenia na problematykę młodszego okresu przedrzymskiego, a zasadniczo powrót do wczesnych koncepcji J. Kostrzewskiego ${ }^{12}$, można zaobserwować od lat 80. zeszłego stulecia w piśmiennictwie Henryka

\footnotetext{
${ }^{12}$ Kostrzewski 1914, 109, 110; 1919a, 341; 1923, 143-145.
} 
Machajewskiego. Badacz ten w swoim omówieniu stanu i potrzeb badań nad okresami przedrzymskim i wpływów rzymskich w Wielkopolsce ponownie wskazał, że dla zrozumienia jego fenomenu duże znaczenie ma pojawianie się tutaj materiałów wywodzących się z kręgu kultury jastorfskiej ${ }^{13}$. Elementy te były marginalizowane po drugiej wojnie światowej - przez sprowadzenie ich obecności wyłącznie do napływu importów ${ }^{14}$, obecnych zarówno w zespołach późnopomorskich ${ }^{15}$, jak wczesnoprzeworskich $^{16}$. Lawinowy przyrost materiałów pochodzących z badań wykopaliskowych, prowadzonych na przecinających Wielkopolskę wielkich inwestycjach liniowych z przełomu XX i XXI w., stał się potwierdzeniem intuicji tegoż badacza. Zorganizowana przezeń w 2002 r. konferencja naukowa Kultura jastorfska na Nizinie Wielkopolsko-Kujawskiej, a zasadniczo wydanie drukiem pochodzących z niej referatów, uzupełnionych dodatkowymi tekstami prezentującymi ówczesny przyrost danych $^{17}$ (ryc. 6), rozpoczęła na nowo dyskusję nad modelem kształtowania się wielkopolskich społeczności przełomu III i II w. p.n.e. Rozwijająca się w tym zakresie twórczość naukowa $\mathrm{H}$. Machajewskiego ${ }^{18}$ i pojawiające się w niej nowe koncepcje stały się niewątpliwą inspiracją dla grona archeologów z Instytutu Prahistorii Uniwersytetu im. Adama Mickiewicza, zajmujących się zagadnieniami okresu przedrzymskiego. Tutaj bowiem, w ostatnich dwóch dekadach, pod auspicjami prof. dr. hab. Tadeusza Makiewicza, zaczęła rozwijać się szkoła badawcza programowo realizująca studia nad tym etapem dziejów ${ }^{19}$. Dzięki inicjatywom naukowców związanych $\mathrm{z}$ tym zespołem postrzeganie młodszego okresu przedrzymskiego w Wielkopolsce zaczęło ulegać znacznemu przewartościowaniu ${ }^{20}$ (ryc. 7, 8). Zagadnienie to nadal stanowi otwarty problem badawczy, priorytetowo realizowany w Zakładzie Prahistorii Powszechnej Epoki Żelaza IP UAM.

\section{AKTUALNA PROBLEMATYKA BADAWCZA W STUDIACH NAD OKRESEM PRZEDRZYMSKIM W WIELKOPOLSCE}

Głównym problemem badawczym we współcześnie prowadzonych w Instytucie Prahistorii UAM studiach nad okresem przedrzymskim stał się ów newralgiczny moment przełomu starszego i młodszego okresu przedrzymskiego. Potrzeba jego poznania wynika bezpośrednio z przywołanego powyżej przyrostu bazy źródłowej. W obowiązującym bowiem ujęciu jest to czas, w którym dochodzi do zastąpienia

\footnotetext{
${ }^{13}$ Machajewski 1986, 274, 281.

${ }^{14}$ Np. Wołągiewicz 1979, 36.

${ }^{15}$ Por. Kaczmarek 1999, 149, 150.

${ }^{16}$ Zob. np. Dąbrowska 1988, 192-204.

${ }^{17}$ Kultura 2004.

${ }^{18}$ Zob. w szczególności: Machajewski, Pietrzak 2008a, 2008b; Machajewski 2010, 2012.

${ }^{19}$ Por. Machajewski 2008, 110, 111.

${ }^{20}$ Zob. np. Michałowski 2006, 2008, 2010, 2014; Michałowski, Teska 2012.
} 
starszego modelu kulturowego, wywodzącego się z tradycji posthalsztackiej - kultury pomorskiej, przez nowy, zlatenizowny model cywilizacyjny - kulturę przeworską. Tymczasem pojawiające się coraz to nowe materiały - m.in. te o silnej proweniencji jastorfskiej - wskazują, że sytuacja kulturowa Wiekopolski przełomu III i II w. p.n.e. nie wpisuje się $\mathrm{w}$ taki bilateralnie ewolucyjny model zmian, z błyskawicznym następstwem wyłącznie dwóch jednostek kulturowych, jaki był dotychczas sugerowany. Zrozumienie tego procesu nastręcza jednak wciąż wielu problemów, generując coraz to nowe pytania badawcze. Obecne zaawansowanie prac nie pozwala bowiem jeszcze na określenie momentu zaniku kultury pomorskiej w Wielkopolsce, co jest jednym z kluczowych zagadnień dotyczących właściwego uchwycenia tutejszej zmienności kulturowej. W literaturze przedmiotu jako dolna granica funkcjonowania tego ugrupowania pojawia się rok 150 p.n.e. ${ }^{21}$ Ta data wydaje się dość realną cezurą dla omawianego regionu. Wiele przesłanek wskazuje, iż z rzeczywistym zanikiem kultury pomorskiej, prawdopodobnie także niezależnie ulegającej procesowi latenizacji, należy się liczyć właśnie w stadium młodszego okresu przedrzymskiego ${ }^{22}$. Wbrew bowiem powszechnym opiniom ${ }^{23}$, najstarszy (łączony $\mathrm{z}$ fazą $\mathrm{A}_{1}$ ) horyzont kultury przeworskiej, będącej synonimem wszelkich wówczas zachodzących w Wielkopolsce przemian, jest dla rzeczonego regionu zaskakująco słabo czytelny. Wynika to z tego, iż materiały, które tutaj zwyczajowo łączone są z rozwojem kultury przeworskiej w jej najwcześniejszym stadium, stanowią tak naprawdę w większości luźne odkrycia o charakterze przypadkowym ${ }^{24}$. Elementy te to $\mathrm{w}$ znacznej mierze odlateńskie formy interkulturowe, które a priori przełożone zostały na przeworski model kulturowy. Identyfikacja chronologiczna zespołów kultury przeworskiej z młodszego okresu przedrzymskiego do dziś bowiem ustalana jest głównie na podstawie obecności w nich wyrobów metalowych, nawiązujących do ich interkulturowych wzorów, powstałych w kręgu kultury lateńskiej i funkcjonujących w szerokiej strefie jej oddziaływania. Wyznacznikami fazy $A_{1}$ w materiałach kultury przeworskiej są przede wszystkim długie, niezdobione zapinki o konstrukcji środkowolateńskiej typu A oraz typu B - wg J. Kostrzewskiego. Należy zatem wyraźnie w tym miejscu zaznaczyć, że obraz, jaki pojawia się w literaturze na podstawie śledzenia dyspersji tego typu znalezisk, nie jest do końca odbiciem rzeczywistego stanu zasiedlenia Wielkopolski przez ludność związaną wyłącznie z kulturą przeworską. Istnieje bowiem duża doza prawdopodobieństwa, iż elementy, które ze względu na swą pozycję chronologiczną uznawane były za przynależne do tego ugrupowania, mogą łączyć się z innymi formacjami kulturowymi - dotyczy to choćby wczesnych zapinek o konstrukcji środkowolateńskiej, spotykanych w zespołach kultury pomorskiej ${ }^{25}$,

\footnotetext{
${ }^{21}$ Krzyżaniak 1972, 128.

${ }^{22}$ Por. np. Kaszewska 1961, 225.

${ }^{23}$ Zob. np. Godłowski 1985, 16.

${ }^{24}$ Dąbrowska 1988, 67.

${ }^{25}$ Dąbrowska 1988, 17.
} 
a także pojawiających się w inwentarzach stanowisk, z których pochodzące materiały nawiązują do zlatenizowanych faz kultury jastorfskiej ${ }^{26}$.

Rekonstrukcja dynamiki początków rozprzestrzeniania się osadnictwa kultury przeworskiej w Wielkopolsce napotyka zatem na poważną barierę, którą stanowi częsty brak precyzyjnych możliwości rozdzielenia w ramach faz $\mathrm{A}_{1}$ i $\mathrm{A}_{2}$ materiałów związanych już stricte $\mathrm{z}$ jej obecnością. Skutkuje to niestety łącznym omawianiem przemian osadniczych, zachodzących $w$ tychże stadiach czasowych ${ }^{27}$. Kulturę przeworską charakteryzuje wówczas znaczne rozproszenie znalezisk. W związku z brakiem (poza skupiskiem kaliskim ${ }^{28}$ ) dużych osad datowanych na młodszy okres przedrzymski i obecnością w fazach $\mathrm{A}_{1}$ i $\mathrm{A}_{2}$ zasadniczo pojedynczych grobów (z wyjątkiem cmentarzyska w Wymysłowie) sytuację tę można tłumaczyć nieustabilizowaną czasowością osadnictwa, wywołaną trwającym jeszcze przemieszczaniem się jej przedstawicieli. Zakładane wówczas stanowiska w większości wyrastają na tzw. surowym korzeniu, lokując się na nisko położonych terenach w pobliżu dolin rzecznych ${ }^{29}$, które, ze względu na możliwość sezonowych podtopień, nie należą do miejsc szczególnie sprzyjających zamieszkaniu. Taka lokalizacja może być sygnałem, iż nowo przybyła ludność rozprzestrzeniała się w rejonach ciągle jeszcze zamieszkałych, na których co atrakcyjniejsze siedliska były nadal zajęte. Zasiedlane były obszary wolne, niewykorzystywane przez autochtonów. Prawdopodobnie dopiero od fazy $\mathrm{A}_{2}$ osadnictwo kultury przeworskiej na większą skalę rozprzestrzenia się w Wielkopolsce, na co wyraźnie wskazuje zwiększenie liczby pochówków łączonych z tą fazą, jak również momenty zakładania tutejszych osad ${ }^{30}$. Natomiast pełna stabilizacja, połączona $\mathrm{z}$ ukształtowaniem się rzeczywistego zasięgu jej zwartego osadnictwa w początkach fazy $A_{3}$, zbiega się $\mathrm{z}$ całkowitym zanikiem stanowisk o cechach jastorfskich $^{31}$.

Z kolei w ustaleniu początkowego momentu napływu elementu jastorfskiego w starszym okresie przedrzymskim w strefę osadnictwa kultury pomorskiej (w tym: do Wielkopolski) ogromnych trudności nastręcza podobieństwo, jakie czytelne jest między tymi dwoma jednostkami ${ }^{32}$. Kultura pomorska w starszym okresie przedrzymskim wchodzi w trzecią fazę swego funkcjonowania. Trudno obecnie wskazać konkretne wyznaczniki charakterystyczne dla tego momentu jej rozwoju. Obserwuje się wówczas niewątpliwe porzucenie stylistyki późnohalsztackiej, któremu to zjawisku towarzyszy recepcja elementu lateńskiego i, jak się wydaje, właśnie jastorfskiego. W inwentarzach proces ten manifestuje się zanikiem zapinek typu Wróblewo,

\footnotetext{
${ }^{26}$ Michałowski 2005, 166-173.

${ }^{27}$ Por. Godłowski 1985, 14, mapa 1.

${ }^{28}$ Por. Michałowski 2003, 88, 89.

${ }^{29}$ Godłowski 1985, 15.

${ }^{30}$ Michałowski 2008, 98, 99.

${ }^{31}$ Godłowski 1985, 35-37; Machajewski, Pietrzak 2004, 101; Michałowski 2008, 100-102.

${ }^{32}$ Zob. Czopek 1991, 1992a, 1992 b.
} 
zamiast których pojawiają się okazy o konstrukcji lateńskiej bądź do niej nawiązujące, takie jak lokalne formy zapinek kowalowickich i wielkopiekarskich ${ }^{33}$, oraz żelazne zapinki zoomorficzne i im pokrewne, a stanowiące naśladownictwa form typowych dla Lt $\mathrm{A}^{34}$. Od horyzontu Lt B1 zmniejsza się jednak diametralnie udział zapinek w materiałach kultury pomorskiej z Wielkopolski. Faza ta wyznaczana jest wówczas przez późne zapinki typu kowalowickiego, nawiązujące formą do celtyckich zapinek typu Münsingen ${ }^{35}$. Nielicznie importowane w okresie Lt B na tereny kultury pomorskiej zapinki duchcowskie obecne są wyłącznie we wschodniej strefie tegoż ugrupowania i nie są reprezentowane w materiałach $\mathrm{z}$ Wielkopolski ${ }^{36}$. W obrządku pogrzebowym kultury pomorskiej starszego okresu przedrzymskiego czytelne staje się odejście od dotychczasowego zwyczaju konstruowania grobów wielopochówkowych na rzecz form jednostkowych i od składania w nich zmarłych do urn twarzowych typu A i B, zastępowanych wówczas przez szerokootworowe naczynia o chropowaconej powierzchni, zdobione listwami plastycznymi ${ }^{37}$, podobnymi do form ceramicznych i sposobów ich zdobienia, jakie można zaobserwować w ceramice jastorfskiej. Wczesny horyzont elementów o cechach jastorfskich, charakterystycznych dla faz Jastorf b, a przede wszystkim Jastorf c, wiąże się w Wielkopolsce $\mathrm{z}$ obecnością $\mathrm{w}$ zespołach kultury pomorskiej pojedynczych form, takich jak kolczyki taśmowate, szpile łopatkowate, szpile z tarczkowatą główką oraz klamry języczkowate $^{38}$. W odniesieniu do dyspersji tych znalezisk trudno mówić o jakichś przejawach samodzielnie funkcjonujących grup osadniczych. Zmiana jakościowa dokonuje się właśnie na przełomie starszego i młodszego okresu przedrzymskiego, a więc na przestrzeni trwania faz Jastorf c i Ripdorf w klasycznym ujęciu G. Schwante$\mathrm{sa}^{39}$. W materiale archeologicznym dostrzec można zintensyfikowanie oddziaływań cywilizacyjnych, docierających do Wielkopolski z obszarów szeroko rozumianego kręgu jastorfskiego. Widać to choćby przez pryzmat zakładania w tym momencie osiedli, takich jak Borzejewo 22, Komorniki 39, Pławce 22, Poznań Nowe-Miasto 226, 278 i 284, na których pojawiają się materiały ceramiczne, znajdujące swój odpowiednik w stylistyce inwentarzy kultury jastorfskiej przełomu faz Jastorf/ /Ripdorf, a także faz Ib/IIa (wg J. Martensa) w kręgu ceramiki Kraghede ${ }^{40}$. Najważniejszą rolę dla ustaleń chronologicznych odgrywają, poza datowaniem ceramicznym $^{41}$, znaleziska ozdób i części stroju typowe dla faz odpowiadających stadium

${ }^{33}$ Kaczmarek 1999, 149, 150; Woźniak 1995, 203, ryc. 2.

${ }^{34}$ Woźniak 1995, 202, 203.

${ }^{35}$ Woźniak 1995, 202.

${ }^{36}$ Woźniak 1995, 203, ryc. 3.

${ }^{37}$ Kaczmarek 1999, 144, 145.

${ }^{38}$ Kaczmarek 1999, 150; Wołągiewicz 1979, 67, 68.

${ }^{39}$ Schwantes 1950.

${ }^{40}$ Chłodnicki, Pietrzak 2004, 172; Kasprowicz 2008, 232, 233; Makiewicz 2004, 242; Machajewski, Pietrzak 2008a, 165, 167; 2008b, 307, 308.

${ }^{41}$ Por. Machajewski, Pietrzak 2004. 
Ripdorf w poszczególnych prowincjach kręgu jastorfskiego. Formą głęboko zakorzenioną w tradycji jastorfskiej, a wciąż jeszcze obecną mimo latenizacji, są szpile, pojawiające się $\mathrm{w}$ zespołach $\mathrm{z}$ początku młodszego okresu przedrzymskiego w Wielkopolsce. Dwie szpile ze skrzydełkami zostały odkryte na cmentarzysku z Białej. Formy te w południowym Szlezwiku-Holsztynie łączą się z fazą Id, trwając nawet do fazy IIIb ${ }^{42}$. W Brandenburgii występują one zasadniczo w pierwszej połowie fazy $\mathrm{IIa}^{43}$. Zbliżoną chronologię wykazują szpile holsztyńskie - obecne, w zależności od ukształtowania główki, w inwentarzach typowych dla faz IIb-IIIa w Szlezwiku-Holsztynie ${ }^{44}$. Z Wielkopolski znane są cztery ich okazy: z Żółwina, Łuszczewa, Sobiejuch i Jutrosina ${ }^{45}$. W zespołach materiałów wiązanych z osadnictwem jastorfskim pojawiają się także formy interkulturowe, łączące się już z procesem latenizacji, jakiej ulega to ugrupowanie na przełomie starszego i młodszego okresu przedrzymskiego. Wśród nich dostrzegamy warianty A, B i H zapinek środkowolateńskich według J. Kostrzewskiego, które są typowymi wyznacznikami starszych, zlatenizowanych faz $\mathrm{w}$ strefie kultury jastorfskiej ${ }^{46}$. Materiały identyfikowane z kulturą jastorfską łączą się zatem w Wielkopolsce ze stylistyką charakterystyczną dla przełomu faz Jastorf c i Ripdorf. Dominującą pozycję mają tu jednak elementy, które można datować na początek młodszego okresu przedrzymskiego, czyli fazę $\mathrm{A}_{1}$. Odpowiada ona końcowi okresu $\mathrm{Lt}_{\mathrm{C}_{1}} \mathrm{i}$ większości $\mathrm{Lt} \mathrm{C}_{2}{ }^{47}$, co $\mathrm{w}$ chronologii kultury jastorfskiej może być powiązane właśnie ze wspomnianym stadium Ripdorf.

\section{ZAKOŃCZENIE}

Przytoczony tutaj bardzo skrótowy i - ze względu na charakter artykułu - jedynie wybiórczy przegląd źródeł odkrywanych dotychczas w Wielkopolsce wstępnie pozwala już dowieść, że w omawianym momencie okresu przedrzymskiego wiele zachodzących przemian wykazywało zewnętrzną genezę. Łączyć ją należy najprawdopodobniej z przybyciem na te tereny grup ludności przynoszących ze sobą własny, w pełni wykształcony już model kulturowy, który to rozwijały przy stałym dopływie nowych idei, docierających z obszarów dla nich macierzystych. Gdzieś pomiędzy nimi znajduje się ludność kultury pomorskiej, ulegająca $w$ międzyczasie procesowi latenizacji. Niestety (co było już podniesione w niniejszym tekście), na wiele z postawionych tutaj hipotez nie jesteśmy jeszcze $\mathrm{w}$ stanie dać w pełni satysfakcjonujących odpowiedzi. Wiążą się one z koniecznością prowadzenia dalszych, coraz bardziej szczegółowych studiów nad zagadnieniami okresu przedrzymskiego.

\footnotetext{
${ }^{42}$ Behrends 1968, 57; Hingst 1980, 46.

${ }^{43}$ Seyer 1982, 18.

${ }^{44}$ Behrends 1968, 56.

${ }^{45}$ Por. Michałowski 2008, ryc. 8.

${ }^{46}$ Bieger 2003, 74; Hachmann 1961, 234; Seyer 1982, 18, 19, 68.

${ }^{47}$ Dąbrowska 1988, 62.
} 
Podejmowane obecnie w Zakładzie Prahistorii Powszechnej Epoki Żelaza działania badawcze dążą zatem do uszczegółowienia i wyjaśnienia przedstawionych procesów. Nie są to, rzecz jasna, jedyne zagadnienia, jakie aktualnie opracowuje zajmujący się tym okresem zespół. Niemniej, jak było to już nadmienione, stanowią one podstawowy punkt w całokształcie programu naukowego przyjętego przezeń na najbliższe lata. Badania nad problematyką okresu przedrzymskiego w Wielkopolsce weszły tym samym w nową fazę. Prace prowadzone obecnie w Instytucie Prahistorii UAM dobrze wpisują się w tradycję tutejszych zainteresowań badawczych, stanowiąc kontynuację dotychczasowych studiów podejmowanych w związku z tą epoką. Należy mieć nadzieję, iż dzięki aktywnej współpracy z innymi jednostkami naukowymi, zarówno w kraju, jak i za granicą, możliwe będzie stworzenie monograficznego ujęcia przywołanego tutaj zagadnienia.

\section{BIBLIOGRAFIA}

Behrends R.-H.

1968 Schwissel. Ein Urnengräberfeld der vorrömischen Eisenzeit aus Holstein, Neumünster.

Bieger A.

2003 Kugelfibeln. Eine typologiach-Chronologische Untersuchung zu den Varianten $F, N$ und $O$ von Beltz, Bonn.

Blume E.

1909 Ausstellung im Keiser Friedrich - Museum vor und frühgeschichtliche Altertümer aus dem Gebiet der Provinz Posen. Austelung im Kaiser Friedrich Museum, Posen.

1911 Kaiser-Friedrich-Museum in Posen, Aus dem Posener Lande. Monatsblat für Heimatkunde 6/7, s. 340-342.

1915 Erwerbungen des Kaiser-Friedrich-Museums zu Posen im Jahre 1910, Mannus 7, s. $145-167$.

Chłodnicki R., Pietrzak R.

2004 Ratownicze badania archeologiczne na trasie autostrady A-2 w 2001 i 2002 roku realizowane przez Ekspedycję Archeostrada Muzeum Archeologicznego w Poznaniu i Poznańskiego Towarzystwa Prehistorycznego [w:] Raport 2001-2002. Wstępne wyniki konserwatorskich badań archeologicznych $w$ strefie budowy autostrad w Polsce za lata 2001-2002, red. Z. Bukowski, Warszawa 2004, s. 165-180.

Czopek S.

1991 Grupa czerniczyńska - prezentacja i analiza źródeł, Prace i Materiały Zamojskie 3, s. $45-143$.

1992a Potudniowo-wschodnia strefa kultury pomorskiej, Rzeszów.

1992b Uwagi o chronologii względnej i periodyzacji materiałów z okresu halsztackiego i starszego okresu przedrzymskiego $\mathrm{w}$ świetle analizy ceramiki kultury pomorskiej [w:] Ziemie polskie we wczesnej epoce żelaza $i$ ich powiazania $z$ innymi terenami, red. S. Czopek, Rzeszów.

Dąbrowska T.

1988 Wczesne fazy kultury przeworskiej, chronologia - zasięg - powiazania, Warszawa.

Dąbrowski K.

1959 Osadnictwo z okresów lateńskiego i rzymskiego na stan. 1 w Piwonicach, pow. Kalisz, Materiały Starożytne 4, s. 7-89. 
Demetrykiewicz W.

$1900 \quad$ Korony bronzowe przedhistoryczne znalezione na obszarze ziem dawnej Polski, Materiały Antropologiczno-Archeologiczne i Etnograficzne 4, s. 70-91.

Dymaczewski A.

1958 Cmentarzysko z okresu rzymskiego w Młodzikowie, w pow. średzkim, Fontes Archaeologici Posnanienses VIII-IX, s. 179-433.

Eggers H.J.

1955 Zur absolute Chronologie der römischen Kaiserzeit im freien Germanien, Jahrbuch des Römisch-Germanischen Zentralmuseums Mainz 2, s. 196-244.

Erzepki B., Kostrzewski J.

1914 Album zabytków przedhistorycznych Wielkiego Księstwa Poznańskiego zebranych w Muzeum Towarzystwa Przyjaciót Nauk w Poznaniu, z. III, Poznań.

Godłowski K.

1985 Przemiany kulturowe i osadnicze w potudniowej i środkowej Polsce w młodszym okresie przedrzymskim i w okresie rzymskim, Wrocław-Warszawa-Kraków-Gdańsk-Łódź.

Hachmann R.

1961 Die Chronologie der jüngeren vorrömischen Eisenzeit. Studien zum Stand der Forschung im nördlichen Mitteleuropa und in Skandinavien, Bericht der Römisch-Germanischen Komission 1960 41, s. 1-275.

Hingst $\mathrm{H}$.

1980 Neumünster-Oberjörn. Ein Urnenfriedhof der vorrömischen Eisenzeit am Oberjörn und die vor- und frühgeschichte Besiedlung auf dem Neumünsteraner Sander, Offa-Bücher 43, Neumünster.

Jasnosz S.

1952 Cmentarzysko z okresu późnolateńskiego i rzymskiego w Wymysłowie, pow. Gostyń, Fontes Archaeologici Posnanienses 2, s. 1-284.

1972 Kultura okresu późnolateńskiego i wpływów rzymskich w Wielkopolsce (Stan badań) [w:] Problemy badań archeologicznych Polski pótnocno-zachodniej, red. J. Żak, Poznań, s. $137-148$.

Kaczmarek M.

1999 Aktualne problemy badań nad kulturą pomorską w Wielkopolsce, Folia Praehistorica Posnaniensia 9, s. 135-172.

Kasprowicz T.

2008 Osada i cmentarzysko ludności z okresu przedrzymskiego na stanowisku 284 (AUT 192) Poznań-Nowe Miasto [w:] Poznań-Nowe Miasto. Źródła archeologiczne do studiów nad pradziejami i wczesnym średniowieczem dorzecza środkowej Warty. Archeostrada. Studia $i$ materiaty z badań wykopaliskowych na autostradzie A2 - odcinek wielkopolski, t. II, red. H. Machajewski, R. Pietrzak, Poznań, s. 225-298.

Kaszewska E.

1961 Materiały z cmentarzyska w Zadowicach, pow. Kalisz (Część III), Prace i Materiały Muzeum Archeologicznego $i$ Etnograficznego $w$ Łodzi, Seria Archeologiczna 6, s. $191-288$

Kostrzewski J.

$1914 \quad$ Wielkopolska w czasach przedhistorycznych, Poznań.

1919a Die ostgermanische Kultur der Spätlatènezeit, 1, 2. Teil, Leipzig und Würzburg.

1919b Über einige Metallgeräte der nordostdeutschen Steinkistengräberkultur der frühen Eisenzeit, Mannus IX (1917), s. 87-96. 
1919- Badania archeologiczne w Wierzenicy w powiecie poznańskim wschodnim, Zapiski 1920 Muzealne IV-V, s. 30-40.

$1923 \quad$ Wielkopolska w czasach przedhistorycznych, Poznań.

1933 Związki między fazą kultury łużyckiej a kulturą grobów jamowych okresu późnolateńskiego, Sprawozdania PAU 43.

1936 Groby szkieletowe późnolateńskie w Wielkopolsce i zagadnienie Silingów, Sprawozdania PAU 46.

Krzyżaniak L.

1972 Niektóre aspekty badań nad kulturą pomorską w Wielkopolsce [w:] Problemy badań archeologicznych Polski pótnocno-zachodniej. Materiały z Sesji Naukowej zorganizowanej z okazji 50-lecia Katedry Archeologii Pradziejowej $i$ Wczesnośredniowiecznej UAM. Poznań, 20-21 listopada 1969 roku, red. J. Żak, Poznań, s. 127-136.

Kultura

2004 Kultura jastorfska na Nizinie Wielkopolsko-Kujawskiej, red. H. Machajewski, Poznań. Machajewski H.

1986 Stan badań nad młodszym okresem przedrzymskim i okresem rzymskim w Wielkopolsce [w:] Stan i potrzeby badań nad mtodszym okresem przedrzymskim i okresem wptywów rzymskich w Polsce. Materiaty z konferencji. Kraków, 14-16 listopada 1984, red. K. Godłowski, R. Madyda-Legutko, Kraków, s. 269-298.

2008 Nowe kierunki badań nad społecznościami Wielkopolski z okresu od I w. n.e. do V/VI w. n.e. [w:] Wielkopolska $w$ dziejach. Archeologia o regionie, red. H. Machajewski, Poznań, s. 107-125.

2010 Studien zu Besiedlung Nordgroßpolens zur Vorrömischen Eisenzeit. Das Problem der Siedlungen vom Typ Posen-Nowe Miasto [w:] Haus-Gehöft-Weiler-Dorf. Siedlungen der Vorrömischen Eisenzeit im nördlichen Mitteleuropa. Internationale Tagung an der Freien Universität Berlin vom 20.-22. März 2009, red. M. Meyer, Rahden/Westf., s. $199-216$.

2012 Z badań nad osadnictwem z okresu przedrzymskiego w Wielkopolsce północnej. Kwestia osad typu Poznań-Nowe Miasto, Gdańskie Studia Archeologiczne 2, s. 97-117.

Machajewski H., Pietrzak R.

2004 Z badań nad ceramiką naczyniową z okresu przedrzymskiego w Wielkopolsce [w:] Kultura jastorfska na Nizinie Wielkopolsko-Kujawskiej, red. H. Machajewski, Poznań, s. $83-121$.

2008a Osada ludności z okresu przedrzymskiego na stanowisku 278 (AUT 191) Poznań-Nowe Miasto [w:] Poznań-Nowe Miasto. Źródta archeologiczne do studiów nad pradziejami i wczesnym średniowieczem dorzecza środkowej Warty. Archeostrada. Studia i materiały z badań wykopaliskowych na autostradzie A2 - odcinek wielkopolski, t. II, red. H. Machajewski, R. Pietrzak, Poznań, s. 153-223.

2008b Osada ludności z okresu przedrzymskiego na stanowisku 226 (AUT 194) Poznań-Nowe Miasto [w:] Poznań-Nowe Miasto. Źródta archeologiczne do studiów nad pradziejami $i$ wczesnym średniowieczem dorzecza środkowej Warty. Archeostrada. Studia i materiaty z badań wykopaliskowych na autostradzie A2 - odcinek wielkopolski, t. II, red. H. Machajewski, R. Pietrzak, Poznań, s. 299-350.

Makiewicz T.

2004 Osady kultury jastorfskiej w Pławcach i Borzejewie, pow. Środa Wlkp., na tle osadnictwa kultury jastorfskiej w Wielkopolsce [w:] Kultura jastorfska na Nizinie Wielkopolsko-Kujawskiej, red. H. Machajewski, Poznań, s. 235-244.

Michałowski A.

2003 Osady kultury przeworskiej z terenów ziem polskich, Poznań. 
2005 Przedmioty osobiste jako dar w grobach kultury jastorfskiej z Wielkopolski [w:] Do, ut des - dar, pochówek, tradycja. Funeralia Lednickie, spotkanie 7, red. W. Dzieduszycki, J. Wrzesiński, Poznań, s. 163-180.

2006 Kultura jastorfska w Wielkopolsce północnej [w:] Pradolina Noteci na tle pradziejowych $i$ wczesnośredniowiecznych szlaków handlowych, red. H. Machajewski, J. Rola, Poznań, s. 183-199.

2008 Okres przedrzymski w Wielkopolsce [w:] Wielkopolska $w$ dziejach. Archeologia o regionie, red. H. Machajewski, Poznań, s. 87-105.

2010 Die Siedlungen der Jastorf-Kultur in Großpolen [w:] Haus-Gehöft-Weiler-Dorf. Siedlungen der Vorrömischen Eisenzeit im nördlichen Mitteleuropa. Internationale Tagung an der Freien Universität Berlin vom 20.-22. März 2009, red. M. Meyer, Rahden/Westf., s. 169-198.

2014 Elements of the Jastorf culture in Wielkopolska. Import of ideas or migration of peoples? [w:] Das Jastorf-Konzept und die vorrömische Eisenzeit im nördlichen Mitteleuropa. Beiträge der Internationale Tagung zum einhundertjährigen Jubiläum der Veröffentlichung der „Ältesten Urnenfriedhöfe bei Uelzen und Lüneburg“ durch Gustav Schwantes, 18.-22. 05.2011 in Bad Bevensen, red. J. Brandt, B. Rauchfuß, Hamburg 2013, s. 287-302.

Michałowski A., Teska M.

2012 Nowe odkrycia figurek Feuerböcke z terenów ziem polskich, Folia Praehistorica Posnaniensia XVII, s. 319-331.

Schwantes G.

1950 Die Jastorf-Zivilisation [w:] Festschrift für Paul Reinecke, Mainz, s. 119-130.

Seyer $\mathrm{H}$.

1982 Siedlung und archäologische Kultur der Germanen im Havel-Spree-Gebiet in den Jahrhunderten vor Beginn u.Z., Berlin.

Undset I.

1882 Das erste Auftreten des Eisen in Nordeuropa, Hamburg.

Wołągiewicz R.

1979 Kultura pomorska a kultura oksywska [w:] Problemy kultury pomorskiej, red. T. Malinowski, Koszalin, s. 33-69.

Woźniak Z.

1995 Kultura pomorska a kultura lateńska [w:] Kultura pomorska i kultura grobów kloszowych. Razem czy osobno, red. T. Węgrzynowicz, M. Andrzejowska, J. Andrzejowski, E. Radziszewska, Warszawa, s. 201-212.

\section{TRADITIONAL AND NEW APPROACHES TOWARDS RECOGNITION OF THE EARLY PRE-ROMAN IRON AGE IN WIELKOPOLSKA}

\section{S u m m a r y}

Specificity and research questions of the Pre-Roman Iron Age distinguish it from other periods. Research on the late Pre-Roman Iron Age in Wielkopolska have had quite a long and significant history. Already in the nineteenth century there had been discoveries reported to dating back 
to that period. Some more general works, inquiring into the specificity of collected finds were based on those early contributions. In particular, it was Józef Kostrzewski's publication Die ostgermanische Kultur der Spätlatènezeit that influenced shaping of the perception of the late PreRoman Iron Age.

Typological and chronological conclusions presented in this publication have been valid ever since, and materials presented there are still an important database for further research on the late Pre-Roman Iron Age. However, a significant increase of the collected data was observed only in the 1950s. Monographs of cemeteries and a settlements in Kalisz-Piwonice which were studied at the time re-systematised knowledge of changes occurring in the late Pre-Roman Iron Age. Thus, they influenced perception of the cultural changes taking place at that time in Wielkopolska, providing benchmarks for any further studies undertaken on the period. From this perspective, it seems that it was when an early stage of the Przeworsk culture, later continuously evolving into the Roman Iron Age, appeared for the first time. This suggests a specific sequence of evolutionary development of local societies. Some overvaluation of looking at the issue of the late Pre-Roman Iron Age, and essentially returning to Kostrzewski's early concepts, may be observed since the 1980s in the writings by Henryk Machajewski. The exponential growth of data collected during rescue excavations conducted in advance of large investments crossing Wielkopolska at the turn of the century, became a confirmation of this researcher's intuition. His new ideas have become, undoubtedly, an inspiration for the group of archaeologists from the Institute of Prehistory at Adam Mickiewicz University, dealing with problems regarding the Pre-Roman Iron Age. Thanks to the initiatives undertaken by researchers associated with the Department of Iron Age of the Institute of Prehistory, the perception of the late Pre-Roman Iron Age in Wielkopolska has undergone some significant reassessment. A key research problem has become a moment of the turn of early Pre-Roman Iron Age. The need for its recognition stems directly from the increase in the source database. A growing number of new materials - including those of a strong Jastorf provenance - indicate that the cultural situation in Wiekopolska at the turn of the third century BC does not fit in the bilateral evolutionary model of changes, with a rapid subsequence of only two cultural units, which was previously suggested. Understanding this process, however, currently still poses many problems, generating more and more new research questions. Preliminarily, however, it might already be proved that at the particular time during the Pre-Roman Iron Age, many of the changes taking place there showed external origin, probably connected with the arrival to the area of populations who bring their own, already fully developed cultural model, but still developing it under a constant inflow of new ideas coming from the areas of their origin. Somewhere in-between them there was a population of the Pomeranian culture, in the meantime going through the process of ,latenisation”. To see this process in more details, further and more detailed research studies of the Pre-Roman Iron Age would be necessary. Therefore, the research of the Pre-Roman Iron Age in Wielkopolska has approached its new stage. The studies currently being undertaken at the Institute of Prehistory of Adam Mickiewicz University fit well in the tradition of research interests of the Institute, being a continuation of the previous studies concerning the period undertaken here. It is hoped that through active collaboration with other scientific centres, both national and international, it will be possible to publish a monographic publication on the subject.

Translated by Lucyna Leśniak 